\title{
A Systematic Literature Review of Total Productive Maintenance on Industries
}

\author{
Setiawan $^{* 1}$, Humiras Hardi Purba ${ }^{2}$ \\ ${ }^{1,2}$ Master of Industrial Engineering Program, Mercu Buana University, Jakarta 1650, Indonesia \\ Email: setiawan.fafa2@gmail.com¹, hardipurba@yahoo.com²
}

\begin{abstract}
Attempts to achieve optimization of machine and equipment maintenance at manufacturing companies over the years have encountered a multitude of problems. Due to equipment losses such as setup and adjustment, minor stops and delays, defective products due to equipment, reduced engine speed, and reduced output has influenced their desire to reach world class manufacturing levels. This paper discusses a large part of the TPM approach in manufacturing companies and provides an overview of the various TPM implementation practices demonstrated by manufacturing companies in the world. Based on review results of the 50 journals about TPM in industries It was found that most of the TPM implementations used the OEE parameter to see the success rate of implementing this TPM. This paper also highlights the variable approach that is most widely used by various practitioners and researchers and evaluates in detail the success factors of implementing TPM and the reasons behind the failure of implementing TPM are also discussed so as to ensure the implementation of TPM can run smoothly and effectively in manufacturing companies.
\end{abstract}

Key words: Total Productive Maintenance (TPM), Overall Equipment Effectiveness (OEE), 8 pillar

\begin{abstract}
Abstrak
Upaya untuk mencapai optimalisasi perawatan mesin dan peralatan di perusahaan manufaktur selama bertahun-tahun telah menemui banyak masalah. Karena kehilangan peralatan seperti penyetelan dan penyesuaian, penghentian dan penundaan kecil, produk cacat karena peralatan, kecepatan engine yang berkurang, dan output yang berkurang telah memengaruhi keinginan mereka untuk mencapai tingkat manufaktur kelas dunia. Makalah ini membahas sebagian besar pendekatan TPM di perusahaan manufaktur dan memberikan gambaran tentang berbagai praktik implementasi TPM yang ditunjukkan oleh perusahaan manufaktur di dunia. Berdasarkan hasil review dari 50 jurnal tentang TPM di industri Ditemukan bahwa sebagian besar dari Implementasi TPM menggunakan parameter OEE untuk melihat tingkat keberhasilan implementasi TPM ini. Makalah ini juga menyoroti pendekatan variabel yang paling banyak digunakan oleh berbagai praktisi dan peneliti serta mengevaluasi secara rinci faktor-faktor keberhasilan penerapan TPM dan juga dibahas alasan dibalik kegagalan penerapan TPM sehingga untuk memastikan pelaksanaan TPM dapat berjalan dengan lancar. dan efektif di perusahaan manufaktur.
\end{abstract}

Kata Kunci: Total Productive Maintenance (TPM), Overall Equipment Effectiveness (OEE), 8 pillar

\section{Introduction}

In Japan, the implementation of Total Productive Maintenance (TPM) can build teamwork that involves all workers from various functions as a culture and a continuous improvement system to achieve zero breakdowns, zero waste and zero accidents (Anh, 2012). Total Productive Maintenance is an effective program and is a new concept established in the equipment maintenance plan (Sethia et al., 2016).

TPM approach allows the manufacturing system to change for the better and has an impact on the company's business. This is a technique that continues to evolve and is applied in all organizations and is able to improve the key business processes used to identify key performance indicators (Nishal et al., 2018). Total Productive Maintenance (TPM) focuses on maximizing equipment performance, establishing a productive maintenance system that optimizes its life cycle, contributing for the continuous improvement and availability, avoiding early equipment wear, being necessary that the maintenance works on preventing with managerial focus (Meca Vital \& Camello Lima, 2020).

Since 50 years ago, the development of the manufactucturing industry was established in Malaysia, the problems of waste, work safety, equipment maintenance, product quality, high costs and performance efficiency are still the spotlight and criticism of many researchers. Various approaches are suggested to obtain good operations management in order to achieve customer satisfaction. The Malaysian government continues to encourage industrial manufacturing activities to improve quality with total solutions in improving safety, quality, low-cost operation management and productive maintenance (Habidin et al., 2017). The Total Productive Maintenance approach is one of the effective operating strategies to reduce production losses caused by breakdowns of equipment and various other types of downtime. Competitive

* Corresponding author 
advantage in a growing market, cost and quality are things that continue to be considered so that we can run the production process at a low cost by increasing the efficiency of their equipment (Nasurdin et al., 2005).

Many studies have been carried out in various countries in order to find the best method for increasing the productivity and quality of a product from the results of the manufacturing process. TPM is one of the approaches used by researchers to achieve the desired results in overcoming zero breakdown and zero defects. In Japan, the TPM philosophy is used to maintain equipment during use in the production process. TPM involves all employees from various work functions in the organization and integrates all worker activities into teamwork to achieve world-class overall equipment effectiveness (OEE). OEE pays attention to the level of availability of machines and equipment, the level of performance at which it operates and the level of production quality as a result of the production process. TPM has 8 pillars which are used as a guide in overcoming organizational problems so that TPM implementation runs more effectively and overall manufacturing performance can improve (Parikh \& Mahamuni, 2015). One of the aims of this paper is to highlight the major problems in equipment maintenance in a manufacturing environment and seek benefits related to the framework, overall equipment effectiveness and implementation of TPM program.

In TPM, we know the term "pillar" in the basic practice of TPM, TPM house stands on eight pillars as the building of a house. These eight pillars are also a system used by companies to maximize production efficiency and effectiveness (Erry Yulian Triblas Adesta \& Prabowo, 2018). JIPM as the originator of TPM suggests that this eight pillar methodology can be used to increase labor productivity, reduce downtime and minor stopped and reduce overall maintenance costs (Fam et al., 2018). The JIPM eight pillar TPM is depicted in Figure
The foundation of TPM house is $5 \mathrm{~S}$, this is a systemic concept to manage an orderly and comfortable workplace by involving all employees to commit to running $5 \mathrm{~S}$ and making it a work culture. With $5 \mathrm{~S}$ being awake, abnormality in the workplace can be clearly seen. Several studies have shown that the level of success of organizations in implementing TPM varies. Overall Equipment Effectiveness (OEE) is one of the most widely used methods to measure the parameters of the success of implementing TPM (Herry et al., 2018). The steps taken are measuring OEE and knowing the biggest factors that influence it by calculating the six big losses (Fahmi et al., 2013). Every manufacturer must decide the right policy in increasing the productivity of machines and equipment, for example in the case of a company in Indonesia (PT Inti Arca Corpora) with ring frame products. In the manufacturing process the product has to go through 124 machines which must always be prime, if there is frequent down time on the machine and unpredictable breakdown, it will damage the planned production schedule. then research is carried out on those 124 machines. The research conducted was to measure the level of effectiveness in the use of machines and equipment, to find the root of the problems that occurred and to provide suggestions for improvements to the company's top management. The first thing the researcher did was to measure the value of the OEE condition before the repair, then identify the six major losses that occurred. The results showed that the value obtained was still below the ideal standard value of world-class OEE, namely $79.9 \%$, where the ideal standard was $85 \%$. The biggest problem that causes the low OEE value is the performance rate factor, namely there is still a speed loss of $17.30 \%$ of the total time lost (Martono, 2014). 1.

TPM

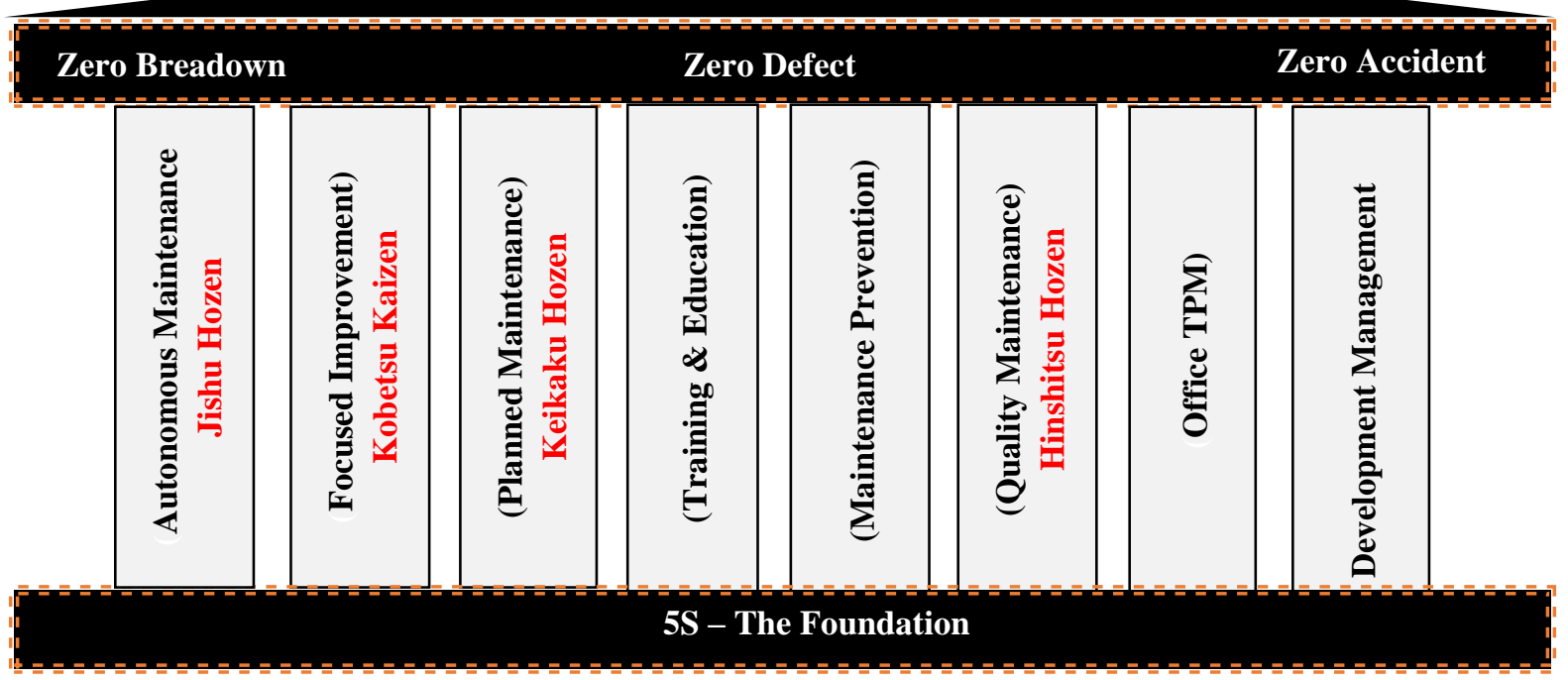

Figure 1. Eight pillars of TPM (suggested by JIPM)

\section{Research Method}


For decades, TPM Technique has existed as an advanced manufacturing technique in helping each production process maximize organizational assets, equipment and produce quality products. But only a few companies succeeded to implement TPM well as a strategy for a comprehensive improvement process. they only apply part of the TPM component and have not realized the benefits that can be achieved through TPM (Ireland \& Dale, 2001).

This paper will show the importance of implementing TPM in organizations, starting from the study framework, the most widely used methods, Overall Equipment Effectiveness, and various TPM implementation practices from various types of manufacturing as well as the obstacles found and what factors support the successful implementation of TPM (Ahuja \& Khamba, 2008). The contribution of TPM program to engaging employees in its implementation is also highlighted here.

The literature on classification of Total Productive Maintenance has so far been very limited. We took 50 random samples of journals discussing TPM for review. This paper reviews and presents an overview of various kinds of TPM implementation practices from various types of manufacturing globally. as well as practical approaches and ways of implementation suggested by various researchers in order to find the maximum success rate and some of the obstacles that need to be avoided in practice. Then compare from various perspectives, then

\section{Results \& Discussion}

\subsection{Paper Summary}

The 50 articles showing implementation TPM in the industrial of manufacturing is selected for review. The selected articles analyzed from the aspect of TPM methodologies, consist of TPM basic concepts and TPM make a summary. For more details can be seen in Figure 2 .

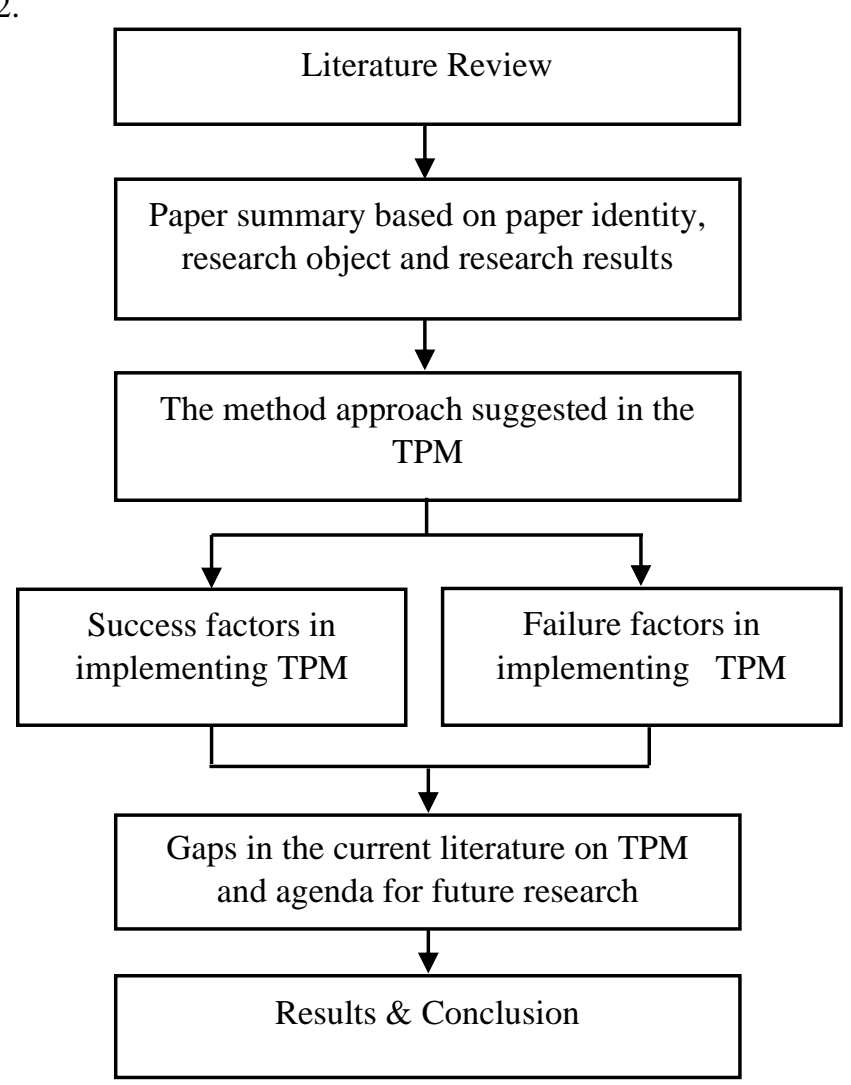

Figure 2. Study Framework

enhancement, then also analyzed by research object and the result. We took a sample of 50 national and international journals with a time span from 1999 to 2020 to determine the use of TPM in organizations. The following is a review of selected articles.

Tabel 1. Paper Summary

\begin{tabular}{|c|c|c|c|}
\hline No & Paper Identity & Research Object & Result \\
\hline 1 & $\begin{array}{l}\text { (Gallesi-Torres et } \\
\text { al., 2020) }\end{array}$ & $\begin{array}{l}\text { Case Study Maintenance TPM } \\
\text { at Manufacturing }\end{array}$ & $\begin{array}{l}\text { After the implementation of TPM there was a decrease of } 35 \% \\
\text { from total downtime that occurred in the plant, a decrease in } \\
\text { maintenance costs by } 16 \% \text { and time available in the machine } \\
\text { by } 784 \text { tons per year. }\end{array}$ \\
\hline 2 & $\begin{array}{l}\text { (Meca Vital \& } \\
\text { Camello Lima, } \\
\text { 2020) }\end{array}$ & $\begin{array}{l}\text { Verify the use of the productive } \\
\text { system capacity at Industrial } \\
\text { Company with TPM. }\end{array}$ & $\begin{array}{l}\text { In the analysis of the evolution results of the TPM pillars, it } \\
\text { was verified the importance of the Specific Improvement and } \\
\text { Planned Maintenance pillars, which, after its implementation, } \\
\text { led to an increase in the OEE metric, with improvements } \\
\text { between } 12.5 \text { and } 33.3 \% \text {, showing the performance } \\
\text { improvement that these pillars provide. }\end{array}$ \\
\hline 3 & $\begin{array}{l}\text { (Palomino-Valles } \\
\text { et al., 2020) }\end{array}$ & $\begin{array}{l}\text { TPM Maintenance at } \\
\text { Construction Sector }\end{array}$ & $\begin{array}{l}\text { The proposed maintenance process simulation can reduce the } \\
\text { average waiting time between failures which can be reduced } \\
\text { by } 7 \text { hours from } 13 \text { hours, meaning that there is a decrease in } \\
\text { downtime by } 15 \% \text {. and an increase in available time by } 90 \% \text {. }\end{array}$ \\
\hline 4 & $\begin{array}{l}\text { (Lukmandono et } \\
\text { al., 2020) }\end{array}$ & $\begin{array}{l}\text { TPM \& FMEA approach at } \\
\text { Manufacturing }\end{array}$ & $\begin{array}{l}\text { The dropped/exited IMC from the operation line was repaired } \\
\text { day at expense of IDR 5,6 MIDR, and rollung slip damage } 10 \\
\text { day at cost of } 34 \text { MIDR. }\end{array}$ \\
\hline
\end{tabular}




\begin{tabular}{|c|c|c|c|}
\hline No & Paper Identity & Research Object & Result \\
\hline 5 & $\begin{array}{l}\text { (Hairiyah et al., } \\
\text { 2019) }\end{array}$ & $\begin{array}{l}\text { Analysis of TPM in the Oil } \\
\text { Palm Processing Industry }\end{array}$ & $\begin{array}{l}\text { The OEE value for the first press machine at KCP station is } \\
68.26 \% \text {, with a significant difference from the international } \\
\text { standard value of } 85 \% \text {. }\end{array}$ \\
\hline 6 & (Azid et al., 2019) & Analysis TPM at Plant & $\begin{array}{l}\text { In practice TPM can be applied to large industries and small } \\
\text { or medium sized factories can be combined with the } \\
\text { application of RCM. }\end{array}$ \\
\hline 7 & $\begin{array}{l}\text { (Irwansyah et al., } \\
\text { 2019) }\end{array}$ & $\begin{array}{l}\text { Improvement TPM at } \\
\text { Manufacturing Beverage } \\
\text { Production. }\end{array}$ & $\begin{array}{l}\text { The average OEE is } 81.13 \% \text { and it is still far below the } \\
\text { standards of world class industries. It was found that the cause } \\
\text { of the low OEE was influenced by Equipment Failure Losses } \\
\text { of } 11.42 \%\end{array}$ \\
\hline 8 & $\begin{array}{l}\text { (Nurprihatin et al., } \\
\text { 2019) }\end{array}$ & Study Case TPM at Manufacture & $\begin{array}{l}\text { OEE value for WP-ATB } 08 \text { machine on line } 7 \text { was } 71.27 \% \text {, } \\
\text { with availability, performance, and quality value are } 82.56 \% \text {, } \\
90.83 \%, 95.04 \% \text { respectively. This OEE value does not yet } \\
\text { reach the world-class standard value }(85 \%) \text { and the lowest } \\
\text { value is the availability factor in terms of percentage disparity } \\
\text { from its individual world-class standard }(7.44 \%) \text {. }\end{array}$ \\
\hline 9 & (Anthony, 2019) & $\begin{array}{l}\text { Application of TPM in Steel } \\
\text { Companies }\end{array}$ & $\begin{array}{l}\text { The biggest factor that caused the low machine effectiveness } \\
\text { was reduced speed losses by } 11.59 \% \text { and equipment failure } \\
\text { losses by } 6.04 \% \text {. }\end{array}$ \\
\hline 10 & $\begin{array}{l}\text { (Priyono et al., } \\
2019 \text { ) }\end{array}$ & TPM at Refined Sugar Factory & $\begin{array}{l}\text { The results of the study illustrate that the implementation of } \\
5 \mathrm{~S} \text { as the basic foundation of TPM in organizations has } \\
\text { reached } 65 \% \text { of the total area. }\end{array}$ \\
\hline 11 & (Ali, 2019) & $\begin{array}{l}\text { Application TPM in Copy } \\
\text { Center at Woldia University }\end{array}$ & $\begin{array}{l}\text { The OEE value for WU copy center was } 35 \% \text { which indicated } \\
\text { that the center needs urgent improvement in equipment } \\
\text { maintenance management program. }\end{array}$ \\
\hline 12 & (Sutoni et al., 2019) & $\begin{array}{l}\text { TPM Analysis at Manufacturing } \\
\text { Motorcycle Parts }\end{array}$ & $\begin{array}{l}\text { The results show that the lowest OEE occurred in October } \\
2017 \text { where a factor of } 6 \text { major losses occurred in lathes such } \\
\text { as set up or adjustment time }(40.3 \%) \text {, decreased speed losses } \\
(19.9 \%) \text {, breakdown machine }(18.5 \%) \text {, Minor stoppage } \\
(17.6 \%) \text {, Rework loss }(3.8 \%) \text {, and scrap }(0 \%) \text {. }\end{array}$ \\
\hline 13 & $\begin{array}{l}\text { (Martomo \& } \\
\text { Laksono, 2018) }\end{array}$ & Case study at Manufacturing & $\begin{array}{l}\text { Obtained an average OEE value of } 79.96 \% \text {, still below the } \\
\text { standards of world class industries }(85 \%) \text {. }\end{array}$ \\
\hline 14 & (Nishal et al., 2018) & $\begin{array}{l}\text { Case study TPM Implementing } \\
\text { at Small And Medium-Sized } \\
\text { Enterprises }\end{array}$ & $\begin{array}{l}\text { The results showed that by involving employees in the } \\
\text { implementation of TPM, create awareness and a sense of } \\
\text { shared responsibility in maintaining the equipment. and this } \\
\text { will have a positive effect on increasing productivity. }\end{array}$ \\
\hline 15 & (Reyes et al., 2018) & $\begin{array}{l}\text { Implementation TPM at } \\
\text { Ecuadorian Footwear Industry }\end{array}$ & $\begin{array}{l}4 \text { phases of the project model such as preparation, } \\
\text { introduction, implementation, and consolidation can be } \\
\text { proposed in carrying out a detailed analysis of failures that } \\
\text { occur on critical machines and have a positive effect on the } \\
\text { application of TPM. }\end{array}$ \\
\hline 16 & (Fam et al., 2018) & TPM at Manufacture Electronic & $\begin{array}{l}\text { The results showed that } 91.2 \% \text { of the total variation of OEE } \\
\text { was influenced by the } 3 \text { pillars of TPM, namely planned } \\
\text { maintenance, autonomous maintenance, and focused } \\
\text { improvement. }\end{array}$ \\
\hline 17 & $\begin{array}{l}\text { (E. Y.T. Adesta et } \\
\text { al., 2018) }\end{array}$ & $\begin{array}{l}\text { Evaluating } 8 \text { Pillars Of TPM } \\
\text { Implementation to } \\
\text { Manufacturing Performance }\end{array}$ & $\begin{array}{l}\text { There is a strong and positive relationship between the TPM } \\
\text { and MP pillar models. where the pillar of TPM can explain } \\
\text { MP variability of } 62.6 \% \text { and } 37.4 \% \text { influenced by other } \\
\text { factors. }\end{array}$ \\
\hline 18 & (Herry et al., 2018) & $\begin{array}{l}\text { Case Study analysis TPM } \\
\text { Implementation at } \\
\text { Manufacturing }\end{array}$ & $\begin{array}{l}\text { The OEE value of the stamping machine is still low due to } \\
\text { reduced speed loss }(53 \%) \text { as the biggest factor affecting } \\
\text { overall downtime. }\end{array}$ \\
\hline 19 & $\begin{array}{l}\text { (Erry Yulian } \\
\text { Triblas Adesta \& } \\
\text { Prabowo, 2018) }\end{array}$ & $\begin{array}{l}\text { TPM Implementation at } \\
\text { Manufacturing Industries }\end{array}$ & $\begin{array}{l}\text { The results of the study provide a reliable CFA model from } \\
\text { TPM, LM and MP and the researchers propose that this model } \\
\text { can be applied to various types of manufacturing industries. }\end{array}$ \\
\hline 20 & $\begin{array}{l}\text { (Prashanth Pai et } \\
\text { al., 2018) }\end{array}$ & $\begin{array}{l}\text { A Study on Usage of Total } \\
\text { Productive Maintenance (TPM) } \\
\text { in Selected SMEs }\end{array}$ & $\begin{array}{l}\text { It was found that around } 52 \% \text { of SMEs have implemented } \\
\text { TPM in their organizations and } 48 \% \text { have not benefited from } \\
\text { implementing TPM. }\end{array}$ \\
\hline
\end{tabular}




\begin{tabular}{|c|c|c|c|}
\hline No & Paper Identity & Research Object & Result \\
\hline 21 & (Manik, 2018) & $\begin{array}{l}\text { OEE approach and identification } \\
\text { of } 6 \text { big lossess in } \\
\text { manufacturing }\end{array}$ & $\begin{array}{l}\text { OEE on the kneader machine is } 81.62 \% \text { with a percentage } \\
\text { factor of six big losses in reduce speeds losses of } 42.66 \% \text { and } \\
\text { idling and minor stoppages of } 31.27 \% \text { of all time losses. }\end{array}$ \\
\hline 22 & $\begin{array}{l}\text { (Habidin et al., } \\
\text { 2017) }\end{array}$ & $\begin{array}{l}\text { A Proposed TPM Tool for Lean } \\
\text { Dashboard, Statistics and } \\
\text { Performance at Manufacturing }\end{array}$ & $\begin{array}{l}\text { The researchers propose a TPM tool that can be used as an } \\
\text { important catalyst for finding maintenance performance that } \\
\text { has an impact on company productivity and competitiveness. }\end{array}$ \\
\hline 23 & $\begin{array}{l}\text { (Brodny \& Tutak, } \\
\text { 2017) }\end{array}$ & $\begin{array}{l}\text { Case Study Application TPM at } \\
\text { Manufacturing }\end{array}$ & $\begin{array}{l}\text { The study concluded that the use of coal mining machines in } \\
\text { Poland was still ineffective, and this was a major problem to } \\
\text { be solved. }\end{array}$ \\
\hline 24 & $\begin{array}{l}\text { (Venkateswaran, } \\
\text { 2017) }\end{array}$ & $\begin{array}{l}\text { Case Study TPM Practices } \\
\text { Adopted at Manufacturing }\end{array}$ & $\begin{array}{l}\text { The results showed that the increase in OEE was due to proper } \\
\text { machine utilization and reduced scrap in the process. }\end{array}$ \\
\hline 25 & $\begin{array}{l}\text { (Amrussalam et al., } \\
\text { 2016) }\end{array}$ & $\begin{array}{l}\text { Measurement and Repair of } \\
\text { TPM in the Garment Industry }\end{array}$ & $\begin{array}{l}\text { The factor greatly affects poor OEE, and reliability is } \\
\text { downtime loss in the machine, which is } 2394,8 \mathrm{sec} / \text { process / } \\
\text { day or } 88,07 \% \text {. }\end{array}$ \\
\hline 26 & (Sethia et al., 2016) & $\begin{array}{l}\text { Study Case TPM at } \\
\text { Contemporary Manufacturing } \\
\text { Scenario }\end{array}$ & $\begin{array}{l}\text { The results of OEE calculations show that the availability rate } \\
\text { reaches } 93.48 \% \text {, the quality rate reaches } 70.90 \% \text { and the } \\
\text { process performance reaches } 90.03 \% \text {. and these results are } \\
\text { still below the world class OEE standards. }\end{array}$ \\
\hline 27 & $\begin{array}{l}\text { (Nursubiyantoro et } \\
\text { al., 2016) }\end{array}$ & $\begin{array}{l}\text { Implementation of TPM in the } \\
\text { Leather Gloves Industry }\end{array}$ & $\begin{array}{l}\text { The OEE value achievement on the hydraulic atom press } \\
\text { machine averaged } 55.24 \% \text {. The focus of improvement that } \\
\text { causes loss factors for the Hydraulic Atom engine is the low } \\
\text { average performance ratio of } 62.11 \% \text { because it is influenced } \\
\text { by idle and minor stoppages and speed losses in the engine. }\end{array}$ \\
\hline 28 & $\begin{array}{l}\text { (Sariyusda et al., } \\
\text { 2016) }\end{array}$ & $\begin{array}{l}\text { Implementation of TPM in the } \\
\text { Leather Gloves Industry }\end{array}$ & $\begin{array}{l}\text { OEE average value in } 2015 \text { was } 79.24 \% \text {. Influential losses are } \\
\text { breakdown losses of } 29.64 \% \text { and reduced speed losses of } \\
10.70 \% \text {. }\end{array}$ \\
\hline 29 & $\begin{array}{l}\text { (Krisnaningsih, } \\
\text { 2015) }\end{array}$ & OEE approach to manufacturing & $\begin{array}{l}\text { OEE in this study was } 65.43 \% \text {. The dominant analysis of Six } \\
\text { big losses using Pareto diagram is setup and adjustment losses } \\
\text { of } 62.84 \% \text { and reduced speed losses of } 29.18 \% \text {. }\end{array}$ \\
\hline 30 & $\begin{array}{l}\text { (Parikh \& } \\
\text { Mahamuni, 2015) }\end{array}$ & $\begin{array}{l}\text { Case Study TPM at } \\
\text { Manufacturing }\end{array}$ & $\begin{array}{l}\text { This study highlights the importance of machine and } \\
\text { equipment maintenance efficiency to achieve optimal } \\
\text { equipment performance. }\end{array}$ \\
\hline 31 & $\begin{array}{l}\text { (Haryono \& } \\
\text { Susanty, 2015) }\end{array}$ & $\begin{array}{l}\text { Application of TPM in Textile } \\
\text { Manufacturing }\end{array}$ & $\begin{array}{l}\text { From the calculations that have been done, the largest reduced } \\
\text { speed loss defect is } 12.952 \% \text {. }\end{array}$ \\
\hline 32 & $\begin{array}{l}\text { (Arya Wiguna, } \\
\text { 2015) }\end{array}$ & $\begin{array}{l}\text { Implementation of the TPM } \\
\text { Program in Manufacturing }\end{array}$ & $\begin{array}{l}\text { Measurement of the effectiveness level of the CJ4 PT } \\
\text { machine. KCI was carried out using the OEE method, its value } \\
\text { is still low compared to the JIPM standard value, which is } \\
<85 \% \text {. }\end{array}$ \\
\hline 33 & (Jain et al., 2014) & $\begin{array}{l}\text { Case Study TPM } \\
\text { Implementation Practice at } \\
\text { Manufacturing Organizations }\end{array}$ & $\begin{array}{l}\text { The research results illustrate that most of the large-scale } \\
\text { industries in the world have expected TPM to increase the } \\
\text { performance of their companies, but the application of TPM } \\
\text { in SMEs is still rare in India. This fact shows that SMEs in } \\
\text { India need a TPM approach in improving performance, } \\
\text { productivity, product quality, preventing equipment failures, } \\
\text { reducing production costs, OEE and others. }\end{array}$ \\
\hline 34 & $\begin{array}{l}\text { (Nurfaizah et al., } \\
\text { 2014) }\end{array}$ & $\begin{array}{l}\text { The application of TPM in } \\
\text { electrical equipment production } \\
\text { companies }\end{array}$ & $\begin{array}{l}\text { The results of the research on the Dobby } 50 \text { No. } 4 \text {, ISIS } 40 \\
\text { No.1, use a maintenance schedule to minimize downtime. }\end{array}$ \\
\hline 35 & $\begin{array}{l}\text { (Dyah Ika } \\
\text { Rinawati, 2014) }\end{array}$ & $\begin{array}{l}\text { TPM Implementation at } \\
\text { Manufacturing company }\end{array}$ & $\begin{array}{l}\text { The biggest factor that affects the low OEE value is the } \\
\text { performance rate with a percentage factor of six big losses at } \\
\text { idling and minor stoppages loss of } 41.08 \% \text { of all time loss. }\end{array}$ \\
\hline 36 & $\begin{array}{l}\text { (Tondato \& } \\
\text { Gonçalves, 2013) }\end{array}$ & $\begin{array}{l}\text { Case Study TPM in } \\
\text { Manufacturing Industry }\end{array}$ & $\begin{array}{l}\text { Overall productivity of industry increased. OEE value is } \\
\text { encouraging and with the passage of time results will be quite } \\
\text { good and may reach a world class OEE value of } 85 \%-90 \% \text {. }\end{array}$ \\
\hline 37 & (Fahmi et al., 2013) & $\begin{array}{l}\text { TPM Implementation at } \\
\text { Manufacturing }\end{array}$ & $\begin{array}{l}\text { The biggest factor that affects the low OEE value is the } \\
\text { performance rate with a percentage factor of six big losses at } \\
\text { the speed loss of } 71.205 \% \text { of the total time loss. }\end{array}$ \\
\hline 38 & (Lazim et al., 2013) & $\begin{array}{l}\text { TPM Performance at } \\
\text { Manufacturing }\end{array}$ & $\begin{array}{l}\text { The results indicated that TPM strategy and planned } \\
\text { maintenance found to be related to cost. }\end{array}$ \\
\hline
\end{tabular}




\begin{tabular}{|c|c|c|c|}
\hline No & Paper Identity & Research Object & Result \\
\hline 39 & (Singh et al., 2013) & $\begin{array}{l}\text { Case Study TPM } \\
\text { Implementation at } \\
\text { Manufacturing }\end{array}$ & $\begin{array}{l}\text { There was an increase in product quality and productivity } \\
\text { which resulted in an increase in equipment effectiveness from } \\
63 \% \text { to } 79 \% \text {. }\end{array}$ \\
\hline 40 & (Anh, 2012) & $\begin{array}{l}\text { Contribution TPM at Japanese } \\
\text { Manufacturing Plants }\end{array}$ & $\begin{array}{l}\text { TPM approach can facilitate organizations, especially } \\
\text { manufacturers, to achieve good product quality and be able to } \\
\text { compete with competitor manufacturers. }\end{array}$ \\
\hline 41 & (Almeanazel, 2010) & $\begin{array}{l}\text { Case Study TPM Review and } \\
\text { OEE Measurement at } \\
\text { Manufacturing }\end{array}$ & $\begin{array}{l}\text { Calculation results obtained Quality rate }(99 \%) \text {, Availability } \\
\text { rate }(76 \%) \text { and performance rate }(72 \%) \text {. }\end{array}$ \\
\hline 42 & $\begin{array}{l}\text { (Didikwahjudi \& } \\
\text { Soejonotjitro, } \\
\text { 2009) }\end{array}$ & $\begin{array}{l}\text { OEE approach and } 6 \text { big losses } \\
\text { in manufacturing }\end{array}$ & $\begin{array}{l}\text { Through the application of TPM the value of OEE in P.T. X } \\
\text { can be increased from } 67.76 \% \text { to } 81.88 \% \text {. }\end{array}$ \\
\hline 43 & $\begin{array}{l}\text { (Ahuja \& Khamba, } \\
\text { 2008) }\end{array}$ & $\begin{array}{l}\text { Case Study TPM Literature } \\
\text { Review and Directions At } \\
\text { Manufacturing }\end{array}$ & $\begin{array}{l}\text { TPM has been proven to be an effective corporate strategy and } \\
\text { has been implemented in various manufacturing industries in } \\
\text { the world which provide consistency in achieving company } \\
\text { performance. }\end{array}$ \\
\hline 44 & (Wang, 2006) & $\begin{array}{l}\text { Evaluating the Efficiency of } \\
\text { Implementing TPM at } \\
\text { Manufacturing }\end{array}$ & $\begin{array}{l}\text { The efficiency score from the Data Envelopment Analysis } \\
\text { (DEA) evaluation can be combined with the OEE score and } \\
\text { the results can be used to classify factories from four } \\
\text { categories. }\end{array}$ \\
\hline 45 & $\begin{array}{l}\text { (Liu \& Rubert, } \\
\text { 2005) }\end{array}$ & $\begin{array}{l}\text { Mapping surface properties of } \\
\text { sinusoidal roughness standards } \\
\text { by TPM at Warwick University }\end{array}$ & $\begin{array}{l}\text { In conclusion have demonstrated that the TPM is capable of } \\
\text { measuring the geometrical and mechanical behaviours of the } \\
\text { chosen roughness standard specimens under a controlled } \\
\text { condition. }\end{array}$ \\
\hline 46 & (Chan et al., 2005) & $\begin{array}{l}\text { Case Study TPM in an } \\
\text { Electronics Manufacturing }\end{array}$ & The productivity of the model machine increased by $83 \%$. \\
\hline 47 & $\begin{array}{l}\text { (Nasurdin et al., } \\
\text { 2005) }\end{array}$ & TPM on Job Characteristics & $\begin{array}{l}\text { The results showed that employee involvement in the } \\
\text { application of TPM had a positive effect on the five } \\
\text { dimensions of work, namely: job identity, type of skills, } \\
\text { special tasks, autonomous maintenance, and feedback. }\end{array}$ \\
\hline 48 & $\begin{array}{l}\text { (One Yoon Seng, } \\
\text { Muhamad Jantan, } \\
\text { 2004) }\end{array}$ & Case study at Manufacturing & $\begin{array}{l}\text { It can be concluded that the extent of both the human and } \\
\text { process-oriented strategies would lead to higher TPM } \\
\text { implementation in the organization. }\end{array}$ \\
\hline 49 & $\begin{array}{l}\text { (Brah \& Chong, } \\
\text { 2004) }\end{array}$ & $\begin{array}{l}\text { Impact of TPM on the } \\
\text { Performance of the } \\
\text { Organization. }\end{array}$ & $\begin{array}{l}\text { The study finds significant support for positive correlation } \\
\text { between TPM and business performance. It finds business } \\
\text { performance of TPM firms to be significantly superior to the } \\
\text { non-TPM firms. }\end{array}$ \\
\hline 50 & $\begin{array}{l}\text { (McKone et al., } \\
1999)\end{array}$ & $\begin{array}{l}\text { Case Study TPM Contextual } \\
\text { View at Manufacturing }\end{array}$ & $\begin{array}{l}\text { The results showed that the managerial contextual factors } \\
\text { from the direction of the factory manager to the workers } \\
\text { greatly influenced the implementation of the TPM program. }\end{array}$ \\
\hline
\end{tabular}

Provides an overview of TPM practices in various manufacturing industries in the world globally. The table also suggests variables and methods suggested by researchers based on the problems faced with regard to equipment maintenance and the results achieved from each organization so that they can be used as benchmarking of the achievement of their application based on the type of similar business. Furthermore, it can be seen also the relationship between TPM and managerial practices in involving employees.

Total Productive Maintenance is a simple tool with many amazing benefits. The widely circulated literature from academics and practitioners has failed to identify contextual problems that affect the success and failure of TPM implementation(McKone et al., 1999). This paper will provide a complete description of the methods commonly used in each country in implementing TPM.

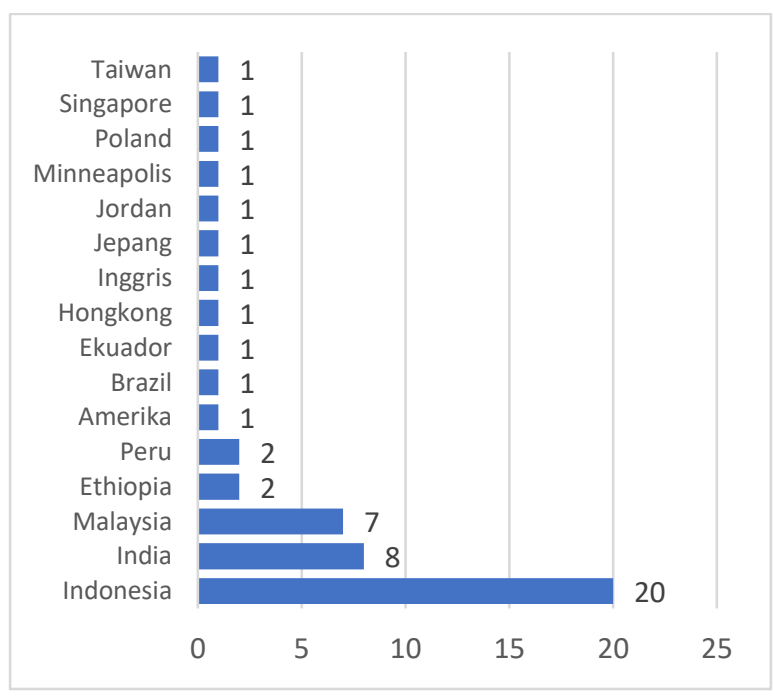

Figure 3. Country of Authors. 


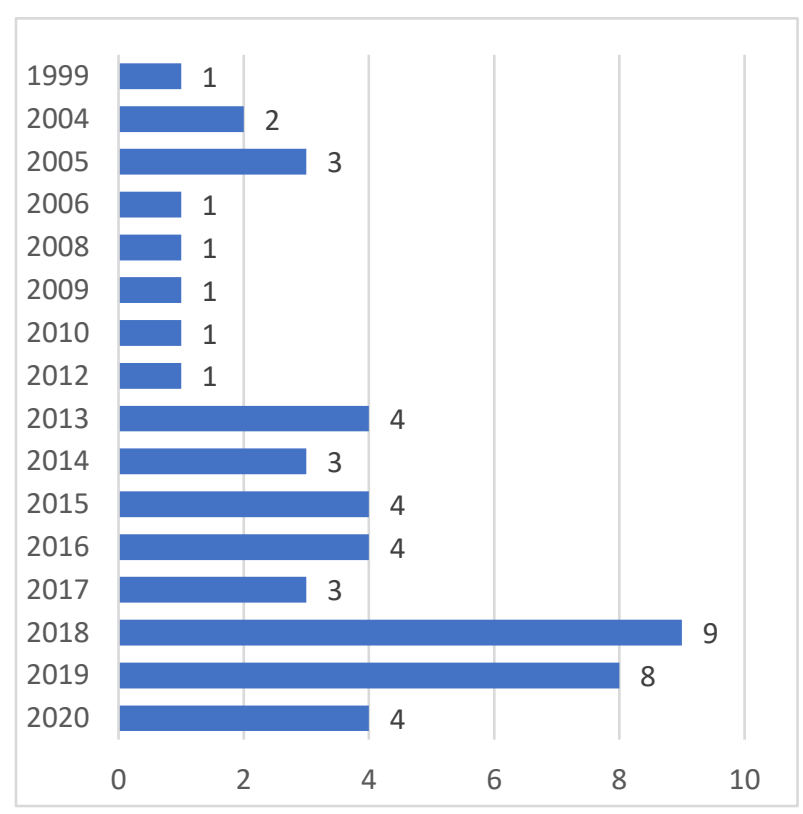

Figure 4. Years of publications.
Figure 3 stated that Indonesia is one of the countries that does a lot of research with the theme of TPM, namely as much as $40 \%$ of the sample taken, followed by India (16\%), Malaysia (14\%), Peru (4\%), Ethiopia (4\%) and others each reaching $2 \%$.

Figure 4 are years of publications are selected by five years range and not longer than 1999, and distribution of the year lead by the year 2018 (9 paper), 2019 ( 8 paper), In 2013, 2015, 2016 and 2020 there were 4 papers. In 2005, 2014, 2017 there were 3 paper, and the rest of the other years are around 2 and 1 papers

By understanding the contents of this sample of 50 journals, we can sort out what variables are best applied to our organization and can figure out the methods and results to be achieved later. Due to every country has a different work culture, this can affect the work ethic of each employee in receiving the TPM program. This literature will provide detailed information on the variables that are widely used by country. for detailed information can be seen in the following discussion

Tabel 2: Research variable base on country

\begin{tabular}{|c|c|c|c|c|c|c|c|c|c|c|c|c|}
\hline \multirow[b]{2}{*}{ Country } & \multicolumn{12}{|c|}{ Research Variable } \\
\hline & OEE & $\begin{array}{c}\text { Six } \\
\text { Big } \\
\text { losses }\end{array}$ & JIT & ТPM & SEM & $\mathrm{RCM}$ & TQM & FMEA & $\begin{array}{c}\text { FUZZY } \\
\text { FMEA }\end{array}$ & $5 \mathrm{~S}$ & RCFA & Lean \\
\hline Amerika & & & 1 & & 1 & & & & & & & \\
\hline Brazil & 1 & & & & & & & & & & & \\
\hline Ekuador & 1 & & & & & & & & & & & \\
\hline Ethiopia & 2 & & & & & & & & & & & \\
\hline Hongkong & 1 & & & & & & & & & & & \\
\hline India & 7 & & & 1 & & & & & & & & \\
\hline Indonesia & 20 & 7 & & & & & & & 1 & 1 & 1 & \\
\hline Inggris & & & & 1 & & & & & & & & \\
\hline Jepang & & & 1 & 1 & & & & & & & & \\
\hline Jordan & 1 & & & & & & & & & & & \\
\hline Malaysia & 4 & & & 1 & 1 & 1 & & 1 & & & & 1 \\
\hline Minneapolis & & & 1 & & & & 1 & & & & & \\
\hline Peru & 1 & & & & & 1 & & 1 & & & & \\
\hline Poland & 1 & & & & & & & & & & & \\
\hline Singapore & & & 1 & & & & 1 & & & & & \\
\hline Taiwan & 1 & & 1 & & & & & & & & & \\
\hline Grand Total & 40 & 7 & 5 & 4 & 2 & 2 & 2 & 2 & 1 & 1 & 1 & 1 \\
\hline
\end{tabular}

Method Approach of Total Productive Maintenance dominated by OEE 60\%, then Six Big Losses 10\%, JIT $7 \%$, TPM $6 \%$, in this calculation one research paper can use more than one tools of Total Productive Maintenance (tabel 2)

\subsection{The TPM method approach (OEE)}

TPM focuses on zero breakdowns and zero defects. The target to be achieved is to eliminate 6 big losses consisting of breakdown machines, setup of equipment or adjustment losses, minor stopage or idling, reduced speed, defects and rework, and reduced production output due to less than optimal equipment conditions (Vigneshwaranp et al., 2015). TPM techniques that can be applied and provide benefits include $5 \mathrm{~S}$ as the company's foundation, One Point Lesson as an indication of conditions before and after improvement, continuous improvement (kaizen), Autonomous maintenance, Pokayoke as an early detection of abnormalities that occur and others (Okpala et al., 2018). OEE methodology helps factory managers see the condition of their production systems by identifying and measuring the 
results of OEE calculations and finding factors that cause problems and prioritizing improvements so that equipment performance can increase and reduce Cost Of Ownership (COO) (Ahuja \& Khamba, 2008), OEE is used as a parameter of equipment performance in the factory and identifies problems in the production process for improvement (Muchiri \& Pintelon, 2008). The most effective way to identify six big losses is to take the OEE approach (Okpala et al., 2018). Every manufacturing industry always tries to provide added value to the products produced, both goods and services. through OEE calculations we can measure the performance of the manufacturer and continuously provide added value to the customer. The OEE model that comprises of equipment timing, six big losses, and perspectives are shown below in figure 5 .

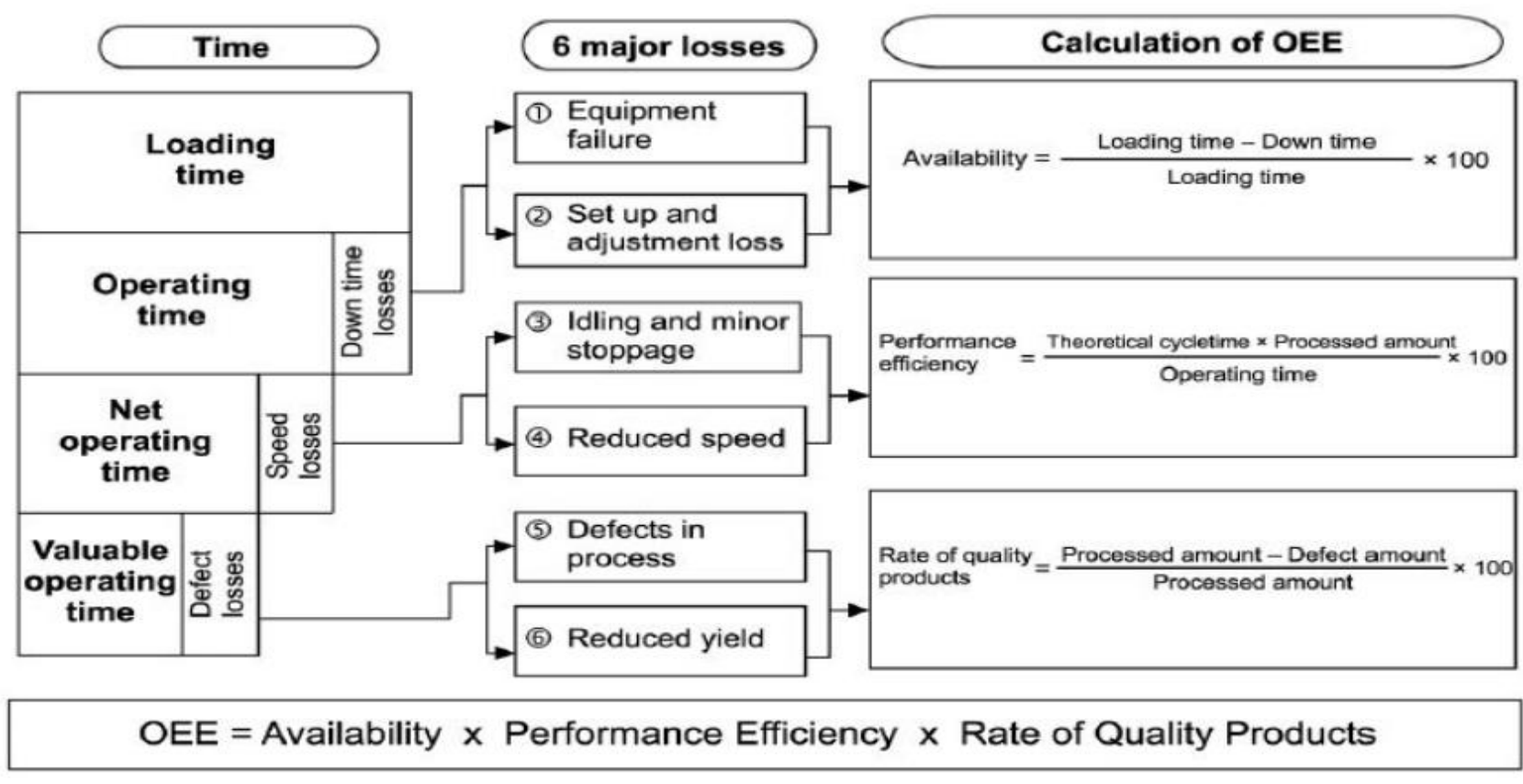

Figure 5. The OEE Model and the Six Big Losses

(Source: Ahuja \& Khamba, 2008)

\subsection{Success factors for TPM implementation}

TPM literature presented in this paper summarizes some of the success criteria in implementing TPM in various manufacturing industries. The first key to success is that we need to combine strategic plans and targets to be achieved. Top management commitment in supporting TPM activities is needed. Because TPM involves many workers, the second key to success is the commitment of all workers in the organization, so that teamwork from various functions is also one of the keys to organizational success, without realizing it this teamwork turns into a positive work culture. Third, it is necessary to change the attitude and point of view of production personnel regarding equipment maintenance so that there is a need for training to workers about the goals and philosophy of TPM. Fourth is the application of the eight pillars of TPM to overcome abnormalities in equipment such as autonomous maintenance, planned maintenance, focus of improvement, preventive maintenance, quality maintenance and others. this activity is to improve the performance of existing equipment in our organization. An overview of the key model for success can be seen how to maintain facilities as shown in Figure 6

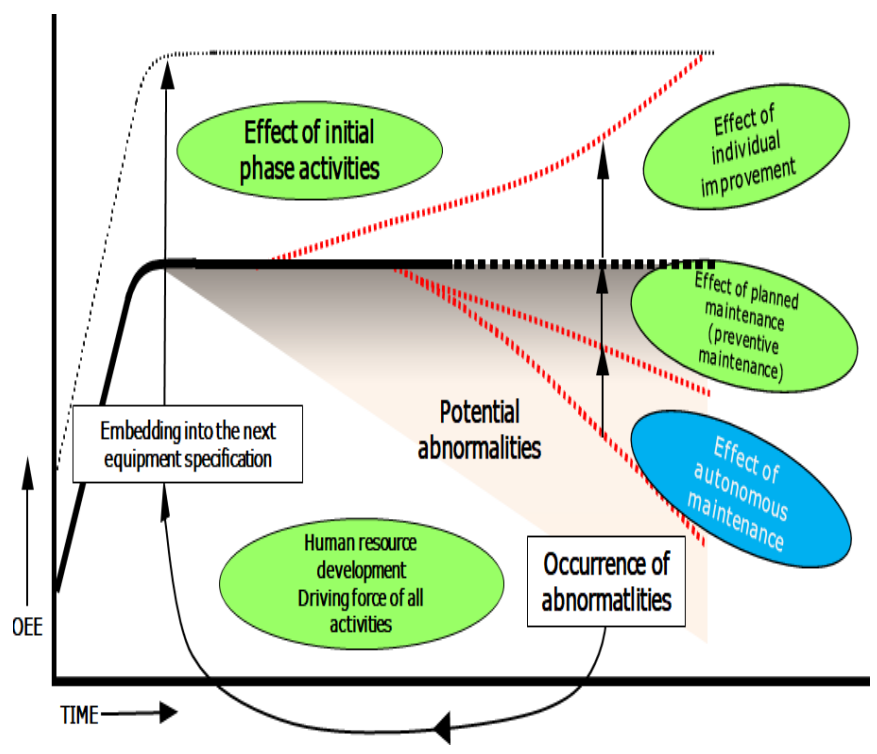

Figure 6. Main activity model of facility maintenance (Source: Motors, 2018)

\subsection{Failure factors in implementing TPM}


The literature on the application of TPM obtained the calculation results of equipment performance without discussing the obstacles in its application. TPM Implementation is not an easy task, manufacturers that have successfully implemented TPM are still relatively small and there are still many failures in its application. This failure can be caused by the commitment and consistency of management that changes in its application, which makes employees confused about the direction and goals to be achieved. a company culture that is not ready to accept changes is also one of the obstacles in implementing TPM, implementing some TPM and excessive expectations of the results to be achieved are also part of the constraints. Employees need the same point of view in its application, the lack of training and education makes employees not aware of the goals and philosophy of TPM itself. The implementation of TPM is not a prestige in itself but a tool by which the organization can achieve its goals.

\subsection{Gaps in the current literature on TPM and agenda for future research}

The literature that we discuss about TPM is how we improve the performance of equipment in the manufacturing industry with various methods offered in order to get organizational efficiency and effectiveness.
The discussion of this paper does not discuss the data collection techniques from the equipment that we use. Along with the development of our times, it is easier for us to collect data on equipment that is more efficient and real time by using IoT, where the equipment is connected to the internet network and convey information in real time. This IoT is one of the tools in industry 4.0

Industrial Revolution 4.0 is a term that is familiar to society. Industry 4.0 is a big leap in the manufacturing sector through the maximum use of information and communication technology. Not only in terms of production, but also the entire value chain to achieve optimal efficiency so as to give birth to a new digitalbased business model. The industrial revolution 4.0 is believed to bring many changes with all the consequences.

In future research we need to improve equipment efficiency by combining 3 components such as Lean, TPM and Industry 4.0 to maximize organizational performance and eliminate waste. equipment needs to be installed with sensors and build automation of processes that are connected via the internet network, so that any abnormality in the production process can be known in real time so that we can quickly take corrective action. Future reasearch frame work shown in figure 7.

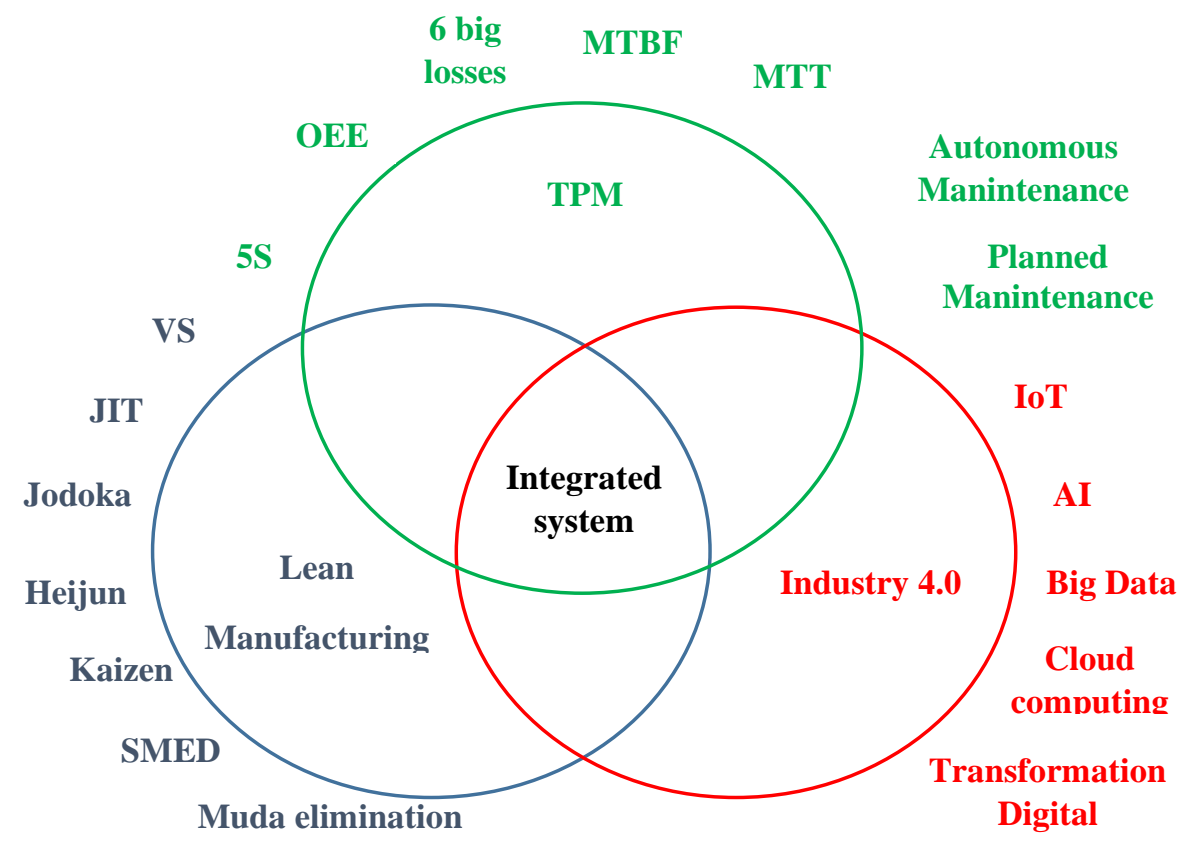

Figure 7. Future Reasearch Framework

\section{Conclusion}

The literature highlights various problems faced by manufacturing that can be resolved by implementing TPM as an organizational strategic in facing global competition. This TPM is here to provide solutions to improve equipment performance in organizational environment. Based on review results of the 50 journals about TPM in industries It was found that most of the
TPM implementations used the OEE parameter to see the success rate of implementing this TPM.

TPM techniques must be understood through training and education, if employees understand the philosophy of TPM and combined with commitment from top management and the involvement of all employees in implementing TPM is the key to the successful implementation of TPM in realizing zero breakdowns, sero defects and zero accidents.. In the 
future research can be developed TPM of basic concepts and enhancement by further develop the scientific basis for basic concept; extends the capabilities of TPM and determines whether it is necessary to develop new tools to strengthen the methodology which is provide highest potential contribution for TPM knowledge. As well as combining TPM with existing tools in Industry 4.0 to get

\section{References}

Adesta, E. Y.T., Prabowo, H. A., \& Agusman, D. (2018). Evaluating 8 pillars of Total Productive Maintenance (TPM) implementation and their contribution to manufacturing performance. IOP Conference Series: Materials Science and Engineering, 290(1). https://doi.org/10.1088/1757899X/290/1/012024

Adesta, Erry Yulian Triblas, \& Prabowo, H. A. (2018). Total Productive Maintenance (TPM) implementation based on lean manufacturing tools in Indonesian manufacturing industries. International Journal of Engineering and Technology(UAE), 7(3.7 Special Issue 7), 156159. https://doi.org/10.14419/ijet.v7i3.7.16261

Ahuja, I. P. S., \& Khamba, J. S. (2008). Total productive maintenance: Literature review and directions. International Journal of Quality and Reliability Management, 25(7), 709-756. https://doi.org/10.1108/02656710810890890

Ali, A. Y. (2019). Application of Total Productive Maintenance in Service Organization. 8(2), 176186. https://doi.org/10.22105/riej.2019.170507.1076

Almeanazel, O. T. R. (2010). Total Productive Maintenance Review and Overall Equipment. Jordan Journal of MMechanical and Industrial Engineering, 4(4), 517-522.

Amrussalam, A., Budi Santoso, P., \& Pambudi Tama, I. (2016). Pengukuran Dan Perbaikan Total Productive Maintenance (Tpm) Menggunakan Overall Equipment Effectiveness (Oee) Dan Root Cause Failure Analysis (Rcfa). Journal of Engineering and Management Industial System, 4(2), $102-108$. https://doi.org/10.21776/ub.jemis.2016.004.02.1

Anh, P. C. (2012). Contribution of Total Productive Maintenance To Quality Performance. The Journal of Japanese Operations Management and Strategy, 3(1), 38-54. https://doi.org/10.20586/joms.3.1_38

Anthony, M. B. (2019). Analisis Penerapan Total Productive Maintenance (TPM) Menggunakan Overall Equipment Efectiveness (OEE) Dan Six Big Losses Pada Mesin Cold Leveller PT. KPS. JATI UNIK: Jurnal Ilmiah Teknik Dan Manajemen Industri, 2(1), 29. https://doi.org/10.30737/jatiunik.v2i2.333

Arya Wiguna. (2015). IMPLEMENTASI PROGRAM TPM (TOTAL PRODUCTIVE MAINTENANCE) MESIN CJ4 DI PT. KIMBERLY-CLARK INDONESIA IGR. OE, 49(23-6), 23-34. http://www.ti.com/lit/ds/symlink/cc2538.html

Azid, N. A. A., Shamsudin, S. N. A., Yusoff, M. S., \& real time information from equipment and also integrate with lean manufacturing to identify and eliminate wastes that occur in organizations. The combination of these 3 tools (TPM, Industry 4.0 and lean manufacturing) is expected to achieve the overall organizational goals, namely profitability and competitiveness.

Samat, H. A. (2019). Conceptual Analysis and Survey of Total Productive Maintenance (TPM) and Reliability Centered Maintenance (RCM) Relationship. IOP Conference Series: Materials Science and Engineering, 530(1). https://doi.org/10.1088/1757-899X/530/1/012050

Brah, S. A., \& Chong, W. K. (2004). Relationship between total productive maintenance and performance. International Journal of Production Research, 42(12), 2383-2401. https://doi.org/10.1080/00207540410001661418

Brodny, J., \& Tutak, M. (2017). Application of Elements of TPM Strategy for Operation Analysis of Mining Machine. IOP Conference Series: Earth and Environmental Science, 95(4). https://doi.org/10.1088/1755-1315/95/4/042019

Chan, F. T. S., Lau, H. C. W., Ip, R. W. L., Chan, H. K., \& Kong, S. (2005). Implementation of total productive maintenance: A case study. International Journal of Production Economics, 95(1), 71-94. https://doi.org/10.1016/j.ijpe.2003.10.021

Didikwahjudi, \& Soejonotjitro, R. (2009). Studi Kasus Peningkatan Overall Equipment Effectiveness ( OEE ) Melalui Implementasi Total Productive Maintenance ( TPM ). Seminar Nasional Teknik Mesin IV, 30(June 2009)

Dyah Ika Rinawati, N. C. D. (2014). Analisis Penerapan Total Productive Maintenance (TPM) Menggunakan Overall Equipment Effectiveness (OEE) dan Six Big Losses pada Mesin Cavitec di PT. Essentra Surabaya. Prosiding Seminar Nasional Teknologi Dan Informatika, Volume 11(1), 21-26. https://doi.org/10.32734/ee.v1i2.245

Fahmi, A., Rahman, A., \& Efranto, R. (2013). Implementasi Total Productive Maintenance Sebagai Penunjang Produktivitas Dengan Pengukuran Overall Equipment Effectiveness Pada Mesin Rotary KTH-8 (Studi Kasus PT.Indonesian Tobacco). Jurnal Rekayasa Dan Manajemen Sistem Industri, 1(1), 75-84. http://jrmsi.studentjournal.ub.ac.id/index.php/jrms i/article/view/15/37

Fam, S. F., Prastyo, D. D., Loh, S. L., Utami, S., \& Yong, D. H. Y. (2018). Total productive maintenance practices in manufacture of electronic components \& boards industry in Malaysia. Journal of Telecommunication, Electronic and Computer Engineering, 10(2-8), 97-101.

Gallesi-Torres, A., Velarde-Cabrera, A., León-Chavarri, C., Raymundo-Ibañez, C., \& Dominguez, F. (2020). Maintenance Management Model under 
the TPM approach to Reduce Machine Breakdowns in Peruvian Giant Squid Processing SMEs. IOP Conference Series: Materials Science and Engineering, 796(1). https://doi.org/10.1088/1757-899X/796/1/012006

Habidin, N. F., Hudin, N. S., Mustaffa, W. S. binti W., Rosli, S. A. M., Ong, S. Y. Y., Fuzi, N. M., \& Zulkifle, N. N. (2017). A Proposed Total Productive Maintenance (TPM) Tool for Lean Dashboard, Statistics and Performance Efficiency in Malaysian Modern Manufacturer. International Journal of Academic Research in Business and Social Sciences, 7(6), 1012-1018. https://doi.org/10.6007/ijarbss/v7-i6/3061

Hairiyah, N., Rizki, R., \& Wijaya, R. A. (2019). Analisis Total Productive Maintenance (Tpm) Pada Stasiun Kernel Crushing Plant (Kcp) Di Pt. X. Jurnal Teknologi Pertanian Andalas, 23(1), 103. https://doi.org/10.25077/jtpa.23.1.103-110.2019

Haryono, L., \& Susanty, A. (2015). Penerapan Total Productive Maintenance Dengan Pendekatan Overall Equipment Effectiveness (OEE) Dan Penentuan Kebijakan Maintenance Pada Mesin Ring Frame Divisi Spinning I Di Pt Pisma Putra Textile.J@ti Undip: Jurnal Teknik Industri, 4(4).

Herry, A. P., Farida, F., \& Lutfia, N. I. (2018). Performance analysis of TPM implementation through Overall Equipment Effectiveness (OEE) and Six Big Losses. IOP Conference Series: Materials Science and Engineering, 453(1). https://doi.org/10.1088/1757-899X/453/1/012061

Ireland, F., \& Dale, B. G. (2001). A study of total productive maintenance implementation. Journal of Quality in Maintenance Engineering, 7(3), 183191. https://doi.org/10.1108/13552510110404495

Irwansyah, D., Harahap, M. R. F., Erliana, C. I., Abdullah, D., Sari, A., Siregar, N., Achmaddaengs, G. S., Indahingwati, A., Sumartono, E., Wilujeng, S., Nurmawati, Subekti, P., Kurniasih, N., Rosalina, F., \& Hartono, H. (2019). Improvement Suggestion Performance of Blowing Machine Line 4 with Total Productive Maintenance (TPM) Method at PT. Coca-Cola Amatil Indonesia MedanUnit. Journal of Physics: Conference Series, 1361(1). https://doi.org/10.1088/17426596/1361/1/012053

Jain, A., Bhatti, R., \& Singh, H. (2014). Total productive maintenance (TPM) implementation practice: a literature review and directions. In International Journal of Lean Six Sigma (Vol. 5, Issue 3). https://doi.org/10.1108/IJLSS-06-2013-0032

Krisnaningsih, E. (2015). Usulan Penerapan TPM dalam Rangka Peningkatan Efektifitas Mesin dengan OEE sebagai Alat Ukur di PT XYZ. Usulan Penerapan Tpm Dalam Rangka Peningkatan Efektifitas Mesin Dengan Oee Sebagai Alat Ukur Di Pt Xyz, 2(2), 13-26.

Lazim, H. M., Salleh, M. N., Subramaniam, C., \& Othman, S. N. (2013). Total Productive Maintenance and Manufacturing Performance: Doeas Technical Complexity in the Production Process Matter? International Journal of Trade, Economics and Finance, 4(6), 380-383. https://doi.org/10.7763/ijtef.2013.v4.321

Liu, X., \& Rubert, P. (2005). Mapping surface properties of sinusoidal roughness standards by TPM. Journal of Physics: Conference Series, 13(1), 20-23. https://doi.org/10.1088/1742-6596/13/1/005

Lukmandono, Prabowo, R., \& Sulistyowati, E. (2020). Analysis of Total Productive Maintenance (TPM) and Failure Mode And Effect Analysis (FMEA) to improve machine effectiveness: A study on Indonesia's sugar mills. IOP Conference Series: Materials Science and Engineering, 885, 012063. https://doi.org/10.1088/1757-899x/885/1/012063

Manik, R. F. (2018). Analisis Produktivitas Dengan Metode Overall Equipment Effectiveness (Oee) Dalam Penerapan Total Productive Maintenance ( Tpm ) Pada Mesin Polymer. 1(004201305051), 53-64.

Martomo, Z. I., \& Laksono, P. W. (2018). Analysis of total productive maintenance (TPM) implementation using overall equipment effectiveness (OEE) and six big losses: A case study. AIP Conference Proceedings, 1931. https://doi.org/10.1063/1.5024085

Martono, N. (2014). Metode penelitian kuantitatif: Analisis Isi dan Analisis Data Sekunder (Ed Revisi). Raja Grafindo Persada.

McKone, K. E., Schroeder, R. G., \& Cua, K. O. (1999). Total productive maintenance: A contextual view. Journal of Operations Management, 17(2), 123144. 6963(98)00039-4

https://doi.org/10.1016/S0272-

Meca Vital, J. C., \& Camello Lima, C. R. (2020). Total Productive Maintenance and the Impact of Each Implemented Pillar in the Overall Equipment Effectiveness. International Journal of Engineering and Management Research, 10(02), 142-150. https://doi.org/10.31033/ijemr.10.2.17

Motors, M. (2018). Sobetsu Module: Total Productive Maintenance.

Muchiri, P., \& Pintelon, L. (2008). Performance measurement using overall equipment effectiveness (OEE): Literature review and practical application discussion. International Journal of Production Research, 46(13), 35173535. https://doi.org/10.1080/00207540601142645

Nasurdin, A. M., Jantan, M., Peng, W. W., \& Ramayah, T. (2005). Influence of Employee Involvement in Total Productive Maintenance Practices on Job Characteristics: The Malaysian Scenario. Gadjah Mada International Journal of Business, 7(3), 287. https://doi.org/10.22146/gamaijb.5580

Nishal, M., Ramprasad, K., Theja, A. J. A., Saravanan, S. A., \& Abishek, S. (2018). Need for Total Productive Maintenance in Sme and. 6, 15-20.

Nurfaizah, U., Adianto, R. H., \& Prassetiyo, H. (2014). Rancangan Penerapan Total Productive Maintenance (TPM) Di Bagian Press II PT. XYZ. Reka Integra, 2(1), 340-353.

Nurprihatin, F., Angely, M., \& Tannady, H. (2019). Total productive maintenance policy to increase effectiveness and maintenance performance using overall equipment effectiveness. Journal of 
Applied Research on Industrial Engineering, 6(3), 184-199.

https://doi.org/10.22105/jarie.2019.199037.1104

Nursubiyantoro, E., Puryani, P., \& Rozaq, M. I. (2016). Implementasi Total Productive Maintenance (Tpm) Dalam Penerapan Overall Equipment Effectiveness (Oee). Opsi, 9(01), 24. https://doi.org/10.31315/opsi.v9i01.2169

Okpala, C. C., Anozie, S. C., \& Ezeanyim, O. C. (2018). The Application of Tools and Techniques of Total Productive Maintenance in Manufacturing. International Journal of Semantic Computing, 8(6), 18115-18121.

One Yoon Seng, Muhamad Jantan, T. R. (2004). Implementing Total Productive Maintenance (TPM) In Malaysian Manufacturing Organisation: An Operational Strategy Study. Kinerja, 9(1), 163173.

Palomino-Valles, A., Tokumori-Wong, M., CastroRangel, P., Raymundo-Ibañez, C., \& Dominguez, F. (2020). TPM Maintenance Management Model Focused on Reliability that Enables the Increase of the Availability of Heavy Equipment in the Construction Sector. IOP Conference Series: Materials Science and Engineering, 796(1). https://doi.org/10.1088/1757-899X/796/1/012008

Parikh, Y., \& Mahamuni, P. (2015). Total Productive Maintenance: Need \& Framework. International Journal of Innovative Research in Advance Engineering, 2(2), 126-130.

Prashanth Pai, M., Ramachandra, C. G., Srinivas, T. R., \& Raghavendra, M. J. (2018). A Study on Usage of Total Productive Maintenance (TPM) in Selected SMEs. IOP Conference Series: Materials Science and Engineering, 376(1). https://doi.org/10.1088/1757-899X/376/1/012117

Priyono, S., Machfud, M., \& Maulana, A. (2019). Penerapan Total Productive Maintenance (TPM) Pada Pabrik Gula Rafinasi di Indonesia (Studi Kasus: PT. XYZ). Jurnal Aplikasi Bisnis Dan Manajemen, 5(2), 265-277. https://doi.org/10.17358/jabm.5.2.265

Reyes, J., Alvarez, K., Martínez, A., \& Guamán, J. (2018). Total productive maintenance for the sewing process in footwear. Journal of Industrial
Engineering and Management, 11(4), 814-822. https://doi.org/10.3926/jiem.2644

Sariyusda, S., Fakhriza, F., \& Putra, J. (2016). Analisa Efektivitas Prokdusi Pada Unit Urea I Dengan Menggunakan Metode Total Productive Maintenance (Tpm) Di Pt. Pupuk Iskandar Muda. Jurnal POLIMESIN, $14(1), \quad 37$. https://doi.org/10.30811/jpl.v14i1.300

Sethia, C. S., Shende, N., \& Dange, S. S. (2016). A Case Study on Total Productive Maintenance in Rolling Mill. International Journal of Scientific Development and Research, 1(5), 283-289. www.ijsdr.org

Singh, R., Gohil, A. M., Shah, D. B., \& Desai, S. (2013). Total productive maintenance (TPM) implementation in a machine shop: A case study. Procedia Engineering, 51(NUiCONE 2012), 592599. https://doi.org/10.1016/j.proeng.2013.01.084

Sutoni, A., Setyawan, W., \& Munandar, T. (2019). Total Productive Maintenance (TPM) Analysis on Lathe Machines using the Overall Equipment Effectiveness Method and Six Big Losses. Journal of Physics: Conference Series, 1179(1). https://doi.org/10.1088/1742-6596/1179/1/012089

Tondato, R., \& Gonçalves, M. B. (2013). Total Productive Maintenance: A casey study. 22nd International Conference on Production Research, ICPR 2013, 12(1).

Venkateswaran, N. (2017). Arabian Journal of Business and Total Productive Maintenance ( TPM ) Practices Adopted at Manufacturing Unit: An Analysis. Arabian Journal of Business and Management Review, 7(4). https://doi.org/10.4172/2223-5833.1000313

Vigneshwaranp, S., Maranp, M., \& Manikandanp, G. (2015). Impact of TPM Implementation: Literature Review and Direction. IJISET-International Journal of Innovative Science, Engineering \& Technology, 2(12), 12. www.ijiset.com

Wang, F. K. (2006). Evaluating the efficiency of implementing total productive maintenance. Total Quality Management and Business Excellence, 17(5), 655-667. https://doi.org/10.1080/14783360600588232 